\title{
What Kind Of Capitalism For Azerbaijan? A Comparative Analysis From Economic View
}

\author{
Ayhan Guney, PhD, Yalova University, Turkey \\ Ilkin M. Sabiroglu, PhD, Qafqaz University, Azerbaijan \\ Cihan Bulut, PhD, Qafqaz University, Azerbaijan
}

\begin{abstract}
Every country has experienced various capital accumulation processes due to their own specific conditions. Differences in these conditions have ensured various countries to enter the process of economic development in dissimilar historical periods. Due to the central characteristics of the previous command economic system and the impact of powerful heritage from the USSR on the bureaucratic administration, Azerbaijan is still having difficulties in transitioning to a free-market economy. Today, the transition to an open market economy for Azerbaijan is not completely realized. This research attempts to investigate the major factors of the formation process of the capitalist economic structure in Azerbaijan before and after the demise of the Soviet Union. It focused on the fundamental role of oil and relatively, the agricultural sector and also looked into the types of capitalism the country is currently experiencing based upon certain criteria and statistical indicators.
\end{abstract}

Keywords: the formation process of capitalist structure; capitalism; transition economy; Azerbaijan; oil

\section{INTRODUCTION}

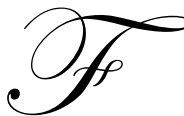

or the first time, Azerbaijan faced real capitalism at the beginning of the 19th Century during transitioning from a feudalism to a capitalist relations system. Currently, Azerbaijan is experiencing the process of capitalism formation for the second time. It is noteworthy that oil has played a crucial role in the process and will be one of the most important factors in the formation of capitalistic structure in the future.

After Azerbaijan gained its independence, it first moved toward transitioning into a market economy, but inevitable remnants of the previous command-economic system and the impact of powerful heritage from the USSR on the bureaucratic administration were main effective factors in shaping the formation process of a capitalist structure and in creating a mixed economic structure instead of establishing a fully free market economy. This research is investigating the possible major factors effecting the formation process of the capitalist structure from the oil sector, specifically, and the agricultural sector, relatively, in Azerbaijan before and after the Soviet Union. It is also determining the type of capitalism that the country is currently experiencing based on certain criteria and statistic indicators.

\section{OIL HISTORY AND ITS EFFECT ON THE FORMATION PROCESS OF CAPITALIST STRUCTURE}

Capitalism was firstly introduced in Azerbaijan in the late 19th century during the period of transitioning from a feudal system to a capitalistic system. Oil played a crucial role in this process. The formation process of capitalism in Azerbaijan occurred again in the late 20th century at a time when the Soviet system collapsed. Again, oil played a vital role in the process. In fact, the existence of oil reserves has been known since the times of Athropatena (ancient Azerbaijan state). In that period, it was mainly used for war tools and called Med Oil (Midiya 
oil). The role of oil played in the rapid industrialization of countries all over the world for centuries and their evergrowing demands for oil have made it a strategic product.

Comparing the processes of the late 19th and the early 20th centuries with the late 20th and early 21 st centuries from the aspect of process of capitalism formation in Azerbaijan, some important points have been identified:

- In the first half of the 19th century, in the territory of Azerbaijan, which was under the rule of Tsar Russia (Russian Empire), the capitalist relations were rather weak. A military-feudal type of administrative system was predominating at that time. In the first half of the 20th century, the administrative system in Azerbaijan, under the Soviet Union, acquired a military-socialist feature which aimed at wiping out capitalist relations in Azerbaijan.

- Industrial development in Russia in the 60s of the 19th century created a sharp need in oil procurement and oil products. In the 60s of the 20th century, the demand on oil increased in Russian enterprises aiming to restore the damages of war and to accelerate industrialization, which led to the construction of oil refinery, machine-engineering, and natural gas production plants in Baku.

- In 1872, the exploitation right of oil fields was rearranged by the Tsar Russia and Iltizam - a form of tax on land property - was removed. Later, these lands were divided and sold to rich people. As a result, the prices of oil-rich lands went up and many oil companies were formed. In 1873, the number of oil companies in Baku was 12, but in the late 19th century, it reached 140 (Yesilot, 2004). Similarly, in the 70s of the 20th century, rapid development in the oil industry was observed. Underwater pipelines were constructed and oil wells were drilled offshore to the depth of 2,800-6,500 meters, and oil production reached 17.3 billion tons in 1970 (Qaffarov et al. 2002). The turning point began after the independence of signing the first oil contract (1994), which was called 'Contract of the Century'.

- With the decrees issued by the Tsar Russia in 1870, the status of foreign oil companies became stronger in Baku; these companies also imported modern oil technologies. In the late 20th century, after 'Contract of The Century', the capital investment of oil companies increased rapidly, and similarly, these companies started to bring in new technologies.

- In the late 19th century, the transition process went from a feudal relations system to capitalism, then to socialism in the beginning of the $20^{\text {th }}$ century and back to capitalism in the late 20th century.

- $\quad$ One of the major common features of the foreign oil companies operating in the late 19th century in Baku was the fact that they were reluctant to make investments in the non-oil sector. After 'Contract of The Century' was signed, the foreign oil companies were also not desirous of investing in other sectors of the country's economy. In the beginning of the 1990s, while two-thirds of oil production technologies in the Soviet Union was produced in Azerbaijan, after the demise of the Soviet Union, foreign companies and investors did not attempt to produce these technologies in Azerbaijan and the foreign investors in the oil sector preferred to import these technologies from foreign countries (Sabiroglu, 2006). In addition, 43.3\% of the foreign capital used in the oil sector in 2006 was spent on housing construction and similar services for foreigners. This accounted for 83.3\% of deficit in service balance (National Bank of Azerbaijan, 2006).

- In the late 19th century, the fact that foreign investors abstained from investing oil income in non-oil sectors negatively influenced the development of capitalist relations in Azerbaijan. In some sense, capitalism means expanded reproduction, so the capital accumulated by foreign oil companies does not have much influence on the development of capitalism in the country. Economic relations reflect the relations between the processes of production, share and distribution of material welfare among people. At the present time, foreign oil companies participate only in production and sharing processes. The exchange process occurs out of the country, and for that reason, the incomes are formed in foreign markets. In other words, the circle of economic relations is not complete in Azerbaijan, which adversely influences the development of capitalist relations. As a matter of fact, more than half of direct investments in the oil and 
gas sector, which were the main sources of continuous economic growth between 1996 and 2006, were repatriated in the form of crude oil (National Bank of Azerbaijan, 2006).

- With the arrangements of 1872, oil riches, such as Tagiyev, Nagiyev, Mukhtarov and others, started to appear in Azerbaijan. In contrast to foreigners, the local oil riches were willing to invest in other spheres of the economy, which brought about a positive impact on the development of capitalist relations. As an example, we can show construction of a textile factory and the establishment of Baku Trade Bank by Tagiyev. At the present time, local oil bourgeoisie does not exist since the oil sector is not privatized. Oil incomes are shared among the Azerbaijan Republic and the foreign companies. However, the state refrains from directing oil dollars to non-oil areas in order to avoid the threat of Dutch Disease. The oil dollars are kept abroad as advised by international institutions. To avoid the threat of Dutch Disease, it is particularly important to develop exporting potential of non-oil sectors.

- The oil sector did not provide sufficient employment. For instance, while only 100-200 of the people were engaged in the oil sector, Tagiyev`s textile factory employed 3,500 people (Yesilot, 2004). Despite that, foreign investments are eagerly made in the oil industry, $90 \%$ of the country's total exports consist of oil and oil products, and only about 60 thousand people work in the oil sector. It makes up only $2 \%$ of the total employment, which is a very low rate.

- Development of the oil industry at the beginning of the 20th century incurred the formation of trade unions. Mutual contracts were signed by oil industrialists and trade unionists on December 30, 1904. As mentioned above, the rate of employment in the oil sector is only $2 \%$ of total employment in Azerbaijan at the present time. In late 2005, mass strikes of oil workers in the foreign oil companies resulted in the formation of trade unions.

Finally, in the late 19th century, rapid development of capitalist relations in Azerbaijan resulted in the establishment of the first state-republic in the East in early 20th century, where in December, 1918 women were granted the right to vote (notice that is earlier than in the USA and France). We must note here that only women over 30 had a right to vote in Britain at that time (HDR, 2009).

As stated before, at the present time, oil incomes are shared among the Azerbaijan Republic and foreign companies since the oil sector is not privatized. The main part of the state's oil incomes is accumulated in the State Oil Fund. So, the usage of oil incomes is not determined by market economy as in the late 19th century; it is now decided by the state. This is one of the key topics of discussions in the country whether the state decisions on this issue are optimal or rational.

\section{THE INFLUENCE OF AGRICULTURAL SECTOR}

One of the processes that accelerated the formation of capitalism in the 19th century was related to land reforms. Tardiness of the government of the Tsar Russia with land reforms could be explained by the fact that Azerbaijani peasants were not officially considered to be land dependent or fortified at the beginning of the second half of the 19th century. In 1861, the South Caucasus Central Reform Committee was established and then state, private (feudal), and peasants land share limits became definite. The land reforms were carried out until May, 1870 when dependence of peasants was abolished and the arrangements on land and tax problems were made. According to new reforms, each male peasant over age 15 was to be given five desiatinas (about 5.5 hectares) of a useful land share; but in practice, peasants who owned less than five desiatinas parcel of land were not given additional land, and only a small part of that land was good for cultivating. Those peasants who possessed a parcel of land over five desiatinas had to relinquish the right over the excessive part of their land, and that part was taken away from them. In addition, a land owner was allowed to keep one-third of his land at his disposal which means that peasants had to share the other two-thirds of their land. The shared land was not given to the property of a peasant; they had to buy that part of the land; so they were allowed for permanent usage. Compared to Russia, the government of Azerbaijan did not financially support the peasants to enable them to be owners of their land. At the same time, they did not oblige the peasants to buy shared lands as they did in Russia. Also, in South Caucasus, the selling prices of land were relatively higher than in the Center (Russia). 
Until the reforms of 1870 , peasants were only economically dependent on feudalists. A peasant only had to pay feudal taxes for using land, which made them free to move to a different place. Major shortage of the arrangement was that it only applied to feudal peasants. Free peasants made up the major portion of all peasants in Azerbaijan and they were out of the coverage of that reform. Despite all limitations, the reform of 1870 was a bourgeois reform by nature. This reform shook the feudal-dependent relations from the base, created an independent peasant class, and developed favorable conditions for the formation of capitalism. As a result of the reform, the landless peasants who moved from rural to urban areas became salaried workers in capitalist enterprises of the city. Besides, the labor force was not as mobile in that period as it is nowadays, which was the reason why the oil riches did not face any difficulties in hiring workers while they made investments in regions.

Nowadays, the land structure in Azerbaijan has been divided and a peasant family owns about eight hectares of land, which has brought about productivity problems in the agriculture (Natig Sabiroglu, 2006). Despite that, high mobility of labor power causes difficulty in regions and slows down the development of capitalist relations. Also, the problems exist in the conversion of land properties for trading purposes.

Table 1 presents important comparative statistics related to agriculture in the selected countries. In the agricultural sector of Azerbaijan, the share of the private sector is almost 100\%. Producers of agricultural productions in the private sector are mainly peasant-family units. Even if these units produced $96 \%$ of the total agricultural products in 2006 from the average land share of 8.4 hectares (Table 2), according to statistic data of 2001, these figures are approximately 22 times less than the average size of U.S. agricultural enterprises and twice lower than the European Union's (15 countries) average figures (Natig Sabiroglu, 2006).

Table 1: Main Agricultural Indicators In Some Selected Countries (2001)

\begin{tabular}{|l|c|c|c|c|}
\hline & USA & EU* & Turkey & Azerbaijan** \\
\hline Total Population ( a million) & 286 & 377 & 68 & 8,4 \\
\hline Agricultural Population (a million) & 6.1 & 15.6 & 20.3 & 4.1 \\
\hline Agricultural Population Ratio in Total Population (\%) & 2.4 & 4.9 & 34.4 & 48.4 \\
\hline Agricultural Sector's Share in GDP (\%) & 1.7 & 1.9 & 14 & 6.9 \\
\hline Average Size of Agricultural Firms (ha) & 180 & 17.4 & 5.9 & 8.4 \\
\hline Agricultural Share in Total Employment (\%) & 2.1 & 4.1 & 39 & 39 \\
\hline
\end{tabular}

* Average indicators for old 15 EU Member States. $\quad * *$ Azerbaijan indicators reflect figures for 2006.

Source: Prepared on the basis of European Union (www.europa.eu.int), Ministry of Agriculture and Rural Affairs of Turkey (www.tarim.gov.tr), and The State Statistical Committee of the Republic of Azerbaijan (www.azstat.org).

Table 2: Agricultural Family-Firms In Azerbaijan (2000-2006)

\begin{tabular}{|c|c|c|c|c|}
\hline & 2000 & 2002 & 2004 & 2006 \\
\hline Agricultural Family-Firms & 3248 & 2589 & 2661 & 2501 \\
\hline Land Parcels Allocated for Them (a thousand ha) & 30.4 & 20.1 & 25.1 & 21 \\
\hline Average Land Parcel Size (ha) & 9.4 & 7.8 & 9.5 & 8.4 \\
\hline
\end{tabular}

Source: State Statistical Committee of Azerbaijan Republic, Azerbaijan in Figures 2007,

http://azstat.org/publications/azfigures/2007/az/013.shtml [25 July 2008].

According to official statistics, the share of population engaged in agriculture is $48.4 \%$ percent and in terms of total employment, it is about $39 \%$; but the share of agricultural products in GDP is only $6.9 \%$. The smallportioned and subdivided land structure is the main reason for very low productivity in the agricultural sector.

Also, under the Labor Law of the 2nd of July, 2001, a small landowner is not considered unemployed, thus the agricultural sector forms a source of hidden unemployment.

\section{Negatively Affecting Factors}

The development of the oil sector was the basic reason for the development of industry in Azerbaijan after its independence. It is impossible to talk about development of the national bourgeois industry since the oil sector is 
under the control of the Azerbaijan government and the foreign companies. Small and subdivided land structure has been the major hurdle for the development of agricultural bourgeoisie. In addition, some events negatively influenced the development of trade bourgeoisie, as well as national bourgeoisie, and the capital accumulation process after its independence (Sabiroglu, 2006):

- $\quad$ One of those events was the loss of hefty sums of people's money in bank deposits during the demise of the Soviet Union. After the specification of inflation indexation, this wealth (insolvent deposit) was estimated at approximate 750-800 million dollars, which was more than GDP of the country in 1991 (700 million U.S. dollars) (State Statistical Committee of Azerbaijan Republic, 1997).

- $\quad$ During the first half of the 1990s, many citizens lost their money when first private and some state banks went bankrupt, which was another important reason that prevented the formation of national bourgeoisie. Consequently, it prevented initial capital accumulation of people. The official figures of the amount of lost wealth have not been announced yet.

- The unsuccessful and dragged privatization process has been another factor that made a negative impact on the process of Azerbaijan national bourgeoisie formation. The process of privatization started in 1995 and has not been finished yet. Actually, the material wealth of the country created during 70 years, as well as physical capital stock of the country, has been dissipated.

- The fourth important reason of preventing formation of people's capitalism and national bourgeoisie in the country is the process of formation of official elite bourgeoisie. The experience of different countries showed that official elite bourgeoisie is reluctant to have an open market system, competitive environment, and to share the market. The concentration of official bourgeoisie forced small entrepreneurs out of the game.

\section{THE RELATIONSHIP BETWEEN TRANSITION AND MIXED ECONOMIES}

The concept of transition of an economy is defined as the transition process from the central planned economy to a market economy. From this aspect, transition economies bear the features of a mixed economy. In the narrow sense, this definition implies the process of economic liberalization by leaving economic activities and prices, stability of macro economic indexes, such as economic development, employment, inflation, and privatization that can provide the transition of public resources to the private sector, establishment of basic methods and regulations that market economy requires (Okur and Cetinkaya, 2007). However, the transition process in Azerbaijan is not limited to these; it started with radical changes in every field of social life, transition from a totalitarian regime to a democracy, from public initiatives to private entrepreneurship, from communal approach to individuality, from planned economy to the efforts to integrate into the globalizing world economy.

In Table 3, the elements and their determinants that form the system in the realms of the established social integrity are given to do a comparable analysis between two extreme systems - centrally controlled economy and market economy, and transition economy. Certainly, it is possible to talk about different system forms based on the social development levels and peculiarities of the countries. The effective work of a market economy depends on a secure coordination in the economy and the existence of the regulations related to the market order by legal institutions. 
Table 3: Basic Factors For Community Forming

\begin{tabular}{|c|c|c|c|c|}
\hline Social Spheres & Basic Factors of System & $\begin{array}{l}\text { Centrally Controlled } \\
\text { Economy }\end{array}$ & Transition Economy & Market Economy \\
\hline \multirow[t]{6}{*}{ Economic } & Coordination & $\begin{array}{l}\text { Central } \\
\text { Administration }\end{array}$ & Guided Market & Market Mechanism \\
\hline & Type of Entrepreneurship & $\begin{array}{l}\text { State Economic } \\
\text { Entrepreneur }\end{array}$ & $\begin{array}{l}\text { Laden Public and Private } \\
\text { Entrepreneur }\end{array}$ & Private Entrepreneur \\
\hline & Pricing & State & Guided Market & Market \\
\hline & Direction & Absolute Equity & $\begin{array}{l}\text { Incentives for Meeting } \\
\text { Basic Needs }\end{array}$ & Competition \\
\hline & Evaluation of Results & $\begin{array}{l}\text { Implementation of } \\
\text { Planned Target }\end{array}$ & Budget and Profit & Profit-Income Principle \\
\hline & $\begin{array}{l}\text { Relationship with other } \\
\text { economies }\end{array}$ & Blocked in System & $\begin{array}{l}\text { Partial openness to } \\
\text { abroad }\end{array}$ & Openness to abroad \\
\hline \multirow[t]{5}{*}{ Political } & Type of Management & Totalitarian & $\begin{array}{l}\text { Mighty Presidency } \\
\text { System }\end{array}$ & Democracy \\
\hline & Type of Representation & Single party & Guided Multiparty & Multiparty \\
\hline & Direction & Ideology & Leader & $\begin{array}{l}\text { Public Opinion and } \\
\text { Coercive Groups }\end{array}$ \\
\hline & Decision Making & Central Authority & $\begin{array}{l}\text { President and } \\
\text { Representative } \\
\text { Parliament }\end{array}$ & $\begin{array}{l}\text { Representative } \\
\text { Parliament }\end{array}$ \\
\hline & Center of Political Power & Bureaucracy & $\begin{array}{l}\text { Bureaucracy and Newly } \\
\text { developed Bourgeoisie }\end{array}$ & $\begin{array}{l}\text { Technocracy, Coercive } \\
\text { Groups }\end{array}$ \\
\hline \multirow{5}{*}{$\begin{array}{l}\text { Social and } \\
\text { Cultural }\end{array}$} & Mentality & Socialist & Nationalist & Individualist \\
\hline & Direction & Socialist Benefit & National Benefit & Individual Benefit \\
\hline & Type of Behavior & $\begin{array}{l}\text { Socialist Institutional } \\
\text { Behavior }\end{array}$ & $\begin{array}{l}\text { Individual Independence } \\
\text { and Social Status }\end{array}$ & $\begin{array}{l}\text { Liberal Institutional } \\
\text { Behavior }\end{array}$ \\
\hline & Motivation & $\begin{array}{l}\text { Ideological } \\
\text { dependence }\end{array}$ & Affinity with Authority & Work and Success \\
\hline & Formation of Values & Ideology & $\begin{array}{l}\text { Belief, Tradition and } \\
\text { Ethics }\end{array}$ & $\begin{array}{l}\text { Legal and Institutional } \\
\text { Norms }\end{array}$ \\
\hline \multirow[t]{5}{*}{$\begin{array}{l}\text { Technological } \\
\text { and Global }\end{array}$} & Priority & Basic Knowledge & Pragmatic & $\begin{array}{l}\text { Scientific Opinion } \\
\text { formed by market }\end{array}$ \\
\hline & Motivation & Public Policy & Technological Attraction & $\begin{array}{l}\text { Innovative } \\
\text { Entrepreneur }\end{array}$ \\
\hline & Direction & $\begin{array}{l}\text { Target of the Central } \\
\text { Government }\end{array}$ & Global Tendency & $\begin{array}{l}\text { Applied Techniques, } \\
\text { Knowledge and } \\
\text { Innovations }\end{array}$ \\
\hline & Dynamics & Defense Oriented R/D & Import Technology & $\begin{array}{l}\text { Global Competition } \\
\text { and R/D }\end{array}$ \\
\hline & $\begin{array}{l}\text { Relationship with other } \\
\text { economies }\end{array}$ & $\begin{array}{l}\text { Dependent within the } \\
\text { block }\end{array}$ & $\begin{array}{l}\text { Integration with the } \\
\text { global system }\end{array}$ & $\begin{array}{l}\text { Unification with the } \\
\text { global system }\end{array}$ \\
\hline
\end{tabular}

Source: Ahmet Okur and Mevlut Cetinkaya, 2007, p. 629.

Table 4 presents the indexes of the process of transition to a capitalist economy in Azerbaijan. As it is seen, while the liberal applications have been practiced in the issues - like convertibility, interest rate, exchange rate, price regulation, and straight investment control - there are problems with the running of the market mechanism in the fields of commercializing land property, the inflation rate, the quality of company rights, and infrastructure. 
Table 4: Progress in Transition In Azerbaijan - Qualitative And Institutional Developments

\begin{tabular}{|l|l|l|}
\hline Areas & Structural Indicators & Current Situation \\
\hline \multirow{5}{*}{ Biberalization and privatization } & Current account convertibility & full \\
\cline { 2 - 3 } competition & Controls on inward direct investment & full \\
\cline { 2 - 3 } & Interest rate liberalization & floating \\
\cline { 2 - 3 } & Exchange rate regime & no \\
\cline { 2 - 3 } & Wage regulation & limited de jure \\
\cline { 2 - 3 } & Tradability of land & yes \\
\hline \multirow{5}{*}{ Infrastructure } & Competition office & low \\
\cline { 2 - 3 } & Quality of insolvency law & malfunctioning \\
\cline { 2 - 3 } & Secured transactions law & very low \\
\cline { 2 - 3 } & Quality of corporate governance law & no \\
\hline \multirow{5}{*}{ Financial sector } & Independent telecoms regulator & no \\
\cline { 2 - 3 } & Independent electricity regulator & no \\
\cline { 2 - 3 } & Separation of railway infrastructure from operations & fully \\
\cline { 2 - 3 } & Independence of the road directorate & no \\
\cline { 2 - 3 } & Quality of concession laws & $12 \%$ \\
\hline \multirow{5}{*}{ Social reform } & Capital adequacy ratio & yes* \\
\cline { 2 - 3 } & Deposit insurance system & low \\
\cline { 2 - 3 } & Quality of securities market laws & $<2 \%(2002)$ \\
\cline { 2 - 3 } & Private pension funds & $0.9 \%(2004)$ \\
\hline
\end{tabular}

* Updated by authors. Insurance of Deposits Acts of The Azerbaijan Republic was passed by the Parliament on December 29, 2006 and ratified by the Presidential Decree No 530 of February 9, 2007. The Deposit Insurance Fund started functioning on August 12, 2007.

Source: European Bank for Reconstruction and Development (EBRD), Transition Development Snapshots, http://www.ebrd.com/country/sector/econo/stats/sib.xls [25 July 2008].

At the present time, Azerbaijan's economy, along with carrying common features of the transition economies, bears the peculiarities of Lucian Cernat's Developmental Capitalism (Table 5). Developmental Capitalism is a kind of interim that occurs between the two main capitalism forms (Cernat, 2001).

Table 5: Varieties Of Capitalism - Main Characteristics

\begin{tabular}{|c|c|c|c|}
\hline \multicolumn{4}{|c|}{ Models of Capitalism } \\
\hline Factors & Anglo Saxon & Continental & Developmental \\
\hline \multicolumn{4}{|c|}{ Macroeconomic } \\
\hline Role of the state & Minimal state & Regulatory state & $\begin{array}{l}\text { Embedded autonomy Pro- } \\
\text { developmental } \\
\text { Interventionism }\end{array}$ \\
\hline $\begin{array}{l}\text { Cooperation between } \\
\text { social partners }\end{array}$ & $\begin{array}{l}\text { Confliction or minimal } \\
\text { contact }\end{array}$ & Extensive at national level & $\begin{array}{l}\text { Formal and informal state- } \\
\text { business networks }\end{array}$ \\
\hline Labor organizations & Fragmented and weak & Strong, centralized unions & Relatively weak \\
\hline \multicolumn{4}{|l|}{ Microeconomic } \\
\hline $\begin{array}{l}\text { Shareholder } \\
\text { sovereignty }\end{array}$ & $\begin{array}{l}\text { Widely dispersed ownership; } \\
\text { dividends prioritized }\end{array}$ & $\begin{array}{l}\text { Banks and other corporations } \\
\text { are major shareholders; } \\
\text { dividends less prioritized }\end{array}$ & $\begin{array}{l}\text { The role of individuals, banks } \\
\text { and intercorporate } \\
\text { shareholders are somewhere in } \\
\text { between. }\end{array}$ \\
\hline Employee influence & Limited & $\begin{array}{l}\text { Extensive though works } \\
\text { councils and codetermination }\end{array}$ & Strong shop floor participation \\
\hline Role of stock exchange & Strong role in corporate finance & Reduced & Intermediate \\
\hline Role of banks & $\begin{array}{l}\text { Banks play a minimal role in } \\
\text { corporate ownership }\end{array}$ & $\begin{array}{l}\text { Important both in corporate } \\
\text { finance and control }\end{array}$ & $\begin{array}{l}\text { Important in corporate finance } \\
\text { but less in corporate control }\end{array}$ \\
\hline
\end{tabular}

Source: Lucian Cernat, "Institutions and Economic Growth: What Model of Capitalism for Central and Eastern Europe?" Conference on Institutions in Transition Slovenia, July, 2001, p. 6. 
The overall evaluation of the above indexes shows that at the beginning, the individual capitalism completion in Azerbaijan was chosen (or compelled to be chosen) as the main development model. It means the labor power markets are rather flexible and stay far away from public interferences. Although the public interferences overdose in the economy, they are not performed for social purposes. However, public interference, as seen from the example of price adjustments made in January, 2007, sometimes contradicts social purposes. In the Azerbaijan Constitution, it is clearly stated that the aim of the state is to build a welfare society, not by means of intensive public interferences and state social budget, but by a free market economy. Though the bureaucratic power of the state of economy is much observed, the country carries the general features of both developmental capitalism and mixed type capitalism.

As a result of his empirical researches, Dani Rodrik, a professor at Harvard University, observed the increase of state power in the economy due to the increase of the external openness rates in the condition of high external risks' uncertainty (Rodrik, 1998). The external openness rate of a country, in terms of economy, is determined by institutional and functional standards. The researches prove that albeit the lower economic independence in Azerbaijan, the functional openness rates (commercial and financial openness) are too high. However, the institutional openness rate is related to liberalization level of commercial and monetary regimes of the countries. It is possible to say that as a result of the moves made and continued to the present day on the extension of the membership process of Azerbaijan with World Trade Organization, the openness rate of the state economy will be promoted.

The absolute dependence of Azerbaijan's export and budget incomes on oil made the country very sensitive to oil prices conjecture in the world market. The indefinite level in terms of foreign trade limits - the indefinite prices and amount of goods in trade - have created strong tendencies for external risks (Rodrik, 1997). Under circumstances in a highly uncertain environment and opening Azerbaijan to the outside, the share of oil in total foreign trade and the speedy influx of oil dollars will cause heightened state influence on non-oil fields. The great expectations from oil incomes promote the state to involve foreign debt in investing activities, especially in infrastructure projects. Unlike the practiced privatization process after independence, it has been very reasonable to form Azerbaijan Investing Company and to consider this company's participation in investment projects in a number of fields ranging from milk production to shipping. One of the aims of founding this company was to make midterm and long-term investments in commercial organizations in the non-oil sector and to promote other investors to invest in these fields.

Though oil countries focus on spending oil incomes transparently, the important issue here is to provide use of these incomes in an effective and productive way. Regardless of the purpose of transition economies adapting to the open-market economy, oil dollars increase the power and empiric role of a state in economy, thus it promotes an increase of interference level. In such a way in the following periods, it is predicted to consolidate the process of establishment of a mixed economy instead of settling on a complete open market economy.

Considering the above-mentioned specific features of oil countries, instead of expecting appropriate economic decisions of state to establish a Welfare State in Azerbaijan, the chances of citizens, civil society organizations, research institutes, and academic organizations for participation in the process of optimizing state decisions must be expanded.

It is well known that oil will be used up one day. The officially adopted decision for a long-term strategy on the management of oil and gas incomes in 2004 envisions spending of oil dollars on such fields as solving problems of infrastructure, making the economy based on knowledge, and developing human resources. The State program considers educating five thousand young people in respected world universities in the fields of information technologies, medicine, and computer engineering between the years 2007 and 2015, which will mainly be financed with oil dollars.

The development of non-oil sectors is on top of the agenda in the country. Establishment of techno parks and developing information and computer technologies are the other priorities. In the last Davos Forum, during the meeting with the President of Microsoft, the President of the Azerbaijan Republic emphasized that the spending of oil dollars on the development of a new economy and arrangement of legal regulations in this direction is one of the 
state's priorities. According to the published report by International Telecommunication Union, Azerbaijan is in the leading position among CIS countries with respect to Digital Opportunities Index.

It is one of the paradoxes that perplex economists; the countries with rich natural resources must develop rapidly compared to others, but in reality, what has been experienced is just the opposite. This paradox is known as Oil Curse or Dutch Disease. Some reasons causing this paradox are economic (oil incomes cause over-value of local currency, home producers become incapable of exporting and compete in importing, which results in non-investing, unemployment and as a result, spread of poverty, etc). Other reasons are political (not developing of democracy, high corruption rate, etc).

To guarantee economic freedom in a country is important to develop entrepreneurship and a non-oil sector, as well as to carry out transition to market economy in a true sense. Otherwise, the consolidation process of mixed type economy, instead of transformation from transition economy to market economy, will be inevitable.

\section{CONCLUSION}

The evidences from the comparative analysis of formation process of capitalist structure before and after the Soviet order helps to explain what is happening in Azerbaijan today. The identification of capitalism type at present, based on definite criterion and indicators, makes it possible to predict the development of capitalism, not only today, but also in the coming period. The findings in our research could be summarized as follows:

- Today, the oil production is generally under the control of the state and the international companies in Azerbaijan. The oil incomes are shared among the Azerbaijan government and the foreign companies. Although the oil production plays a very significant role in terms of the economic development and welfare, it is just the opposite in the processes in the second half of the 19th century - implicitly it prevents the development of entrepreneur power in society and it slows down the formation of capitalist production relations and production styles in the country, leading to the establishment of Rentier State.

- $\quad$ The main part of oil incomes is saved up in the state oil fund or some part of it is directly transferred to the state budget. Therefore, how to use the oil incomes is not decided by the market as in the 19th century. On the contrary, it is decided by the state. The state generally acts as a financer in the infrastructure projects instead of participating as a producer in the economy because the state does not want to contradict the conception of a liberal state and the logic of privatization practices after independence. The optimum rationalism of state decisions on usage of oil incomes is one of the important topics of discussions in the country. What, in particular, must be developed in order to avoid Dutch Disease in the non-oil sector with high potential of exports?

- $\quad$ Today in Azerbaijan, the agriculture with highly divided land structure and main producers being familyvillage enterprises owning an average of eight hectares of land is experiencing the problem of productivity. The problems exist in commercialization of land property. Besides, high mobility of work power prevents the development of capitalist relations in the regions. Generally, the present situation in agriculture tends to prevent the capitalist structure formation process, which is exactly the opposite of the process after the second half of the 19th century.

- $\quad$ The main reason for rapid industrial development in Azerbaijan after its independence was development of the oil sector. It is impossible to talk about the developed national industrial bourgeoisie since the oil sector is under the control of the Azerbaijan state and the foreign companies. The divided and small land structure prevents the formation of agricultural bourgeoisie. Also, some processes experienced after the independence affected mainly trade bourgeoisie, the development of national bourgeoisie and capital accumulation process. In the second half of the 19th century, the process of formation of the Azerbaijan bourgeoisie has been reminded earlier in the article recalling the names of several famous bourgeois. However, today it is very difficult to mention the name of a famous businessman who is well known to the public. 
Finally, the research indicates that the oil producing and exporting countries focus on transparency in spending of oil incomes. In fact, most important is the usage of oil incomes in an effective and productive way. Even though the major aim of transition economies is to apply the free-market economy, oil dollars unintentionally increase the importance and weight of the state in the economic structure.

\section{AUTHOR INFORMATION}

Ayhan Guney, Ph.D., is currently working Assistant Professor in Economics at Yalova University in Turkey since 2010. He graduated from the Faculty of Political Science of Ankara University in 1995. He completed Master of Arts in Economics at Fatih University. He got a PhD degree in economics from both the Science Academy and Istanbul University. He worked as the Director of International Office and MBA Coordinator and thought microeconomics, macroeconomics and international economics in English language at Qafqaz University, Baku, for 2007-2010 academic years. He was a visitor scholar at the Queen's Belfast University, Belfast, UK for a term in 2009.

Ilkin M. Sabiroglu, Ph.D., is currently working as Economics Teacher/Lecturer at Qafqaz University, Baku, Azerbaijan. He's been teaching the courses of macroeconomics, economic history. He graduated from the Faculty of Economics and Administrative Sciences of Gazi University in 1999, and completed Master of Arts in Theory of Economics at Azerbaijan State Economic University in 2001. He got the PhD degree in Economics from Istanbul University in 2008.

Cihan Bulut, Ph.D., is currently working as Vice President at Qafqaz University, Baku, Azerbaijan since 2009. He graduated from the Faculty of Political Science of Istanbul University in 1994. He completed Master of Arts in Economics at Istanbul University. He got also a PhD degree in Economics from Istanbul University in 2002. He worked as the Dean of Faculty of Economics and Administrative Sciences for 2006-2009 academic years. He's been teaching the courses of macroeconomics, international economics and Azerbaijani economy in English and Azerbaijani languages at Qafqaz University, Baku, since 2000.

\section{REFERENCES}

1. Cernat, L., (2001) Institutions and Economic Growth: What Model of Capitalism for Central and Eastern Europe?, Paper prepared for the Conference on Institutions in Transition Slovenia, July, http://www.umar.gov.si/fileadmin/user_upload/konference/06/15_cernat.pdf [25 July 2008], pp. 1-25.

2. Commission of the European Communities, Commission Staff Working Paper, 2005. European Neighbourhood Policy, Country Report, Azerbaijan, http://ec.europa.eu/world/enp/pdf/country/azerbaijan_country_report_2005_en.pdf [25 July 2008].

3. European Bank for Reconstruction and Development, Transition Report, 2004. London, http://www.ebrd.com/pubs/econo/series/tr.htm [25 July 2008].

4. Fischer, S. and Gelb, A., (1991), The Process of Socialist Economic Transformation, The Journal of Economic Perspectives, Vol. 5, No. 4, Autumn, pp. 91-105.

5. HDR, 2009. Human Development Report, UNDP.

6. Lane, D., (2000), What Kind of Capitalism for Russia? A comparative Analysis, Communist and PostCommunist Studies, No 33, pp. 485-504.

7. Lodge, G. C., (1987) Introduction, Ideology and Country Analysis. Ideology and National Competitiveness: An Analysis of Nine Countries, eds. George C. Lodge and Ezra F; Vogel, Harvard Business Scholl Press, Boston Massachusetts.

8. Michel, A., (1992), Capitalism against Capitalism, Trans. by Cemil Oktay, Husnu Dilli, Afa Publishing, Istanbul.

9. National Bank of Azerbaijan, 2006. Balance of Payments of the Azerbaijan Republic for 2006, http://www.nba.az/download/melumatlar/tediyye balansi/ted_balansi_2006.pdf [25 July 2008].

10. National Bank of Azerbaijan, Report on Inflation for January-April 2007. http://www.nba.az/download/Pul_siyaseti/inflyasiya/04_2007.pdf [25 July 2008].

11. Nezirli, I., (2006), Importance of Multi-Step Social Security System, New Economy, Business and Economy Monthly Magazine, No. 4, October, pp. 66-71. 
12. Okur, A. and Cetinkaya, M., (2007), A Complex Approach to Period of Transition to Open Market Economy In Caucasus and Central Asia, Caucasus and Central Asia in the Globalization Process, II International Congress, II. Book, 2-5 May, Baku, p. 626-644.

13. Qaffarov, T. et al., (2002) History of Azerbaijan, 3rd edition, Casioglu Publishing, Baku.

14. Rodrik, D., (1998), Why do More Open Economies Have Bigger Governments?, Journal of Political Economy, 106 (5), 997-1032, ISBN: 0-88132-241-5, pp. 997-1032.

15. Rodrik, D., (2001), The Global Governance of Trade as if Development Really Mattered, New York, United Nations Development Programme, http://ksghome.harvard.edu/ drodrik/undptrade.pdf [25 July 2008], pp. 1-39.

16. Sabiroglu, I., (2006) Capitalism Doesn't Resemble Capitalism, CBS Publishing House, Baku.

17. Sabiroglu, N., (2006), Small Land Ownership Hampers the Development of Agriculture Sector, New Economy, Business and Economy Monthly Magazine, No 4, Fall, pp. 60-63.

18. State Program on Education of Azerbaijan Youth Abroad in 2007-2015, http://www.xalqqazeti.com/public/print.php?lngs=aze\&ids=9529 [25 July 2008].

19. State Statistical Committee of Azerbaijan Republic, 1997. National Accounts of Azerbaijan for 1990-1995, Statistical Issue, Baku.

20. The Constitution of the Republic of Azerbaijan, 1995.12 November. Baku.

21. The Fraser Institute, Economic Freedom of the World, 2007. Annual Report, http://www.freetheworld.com/2007/EFW2007BOOK2.pdf [25 July 2008].

22. Williamson, J., (2003), From Reform Agenda to Damaged Brand Name, Finance and Development, International Monetary Fund, 30 September, received from http://www.imf.org/external/pubs/ft/fandd/2003/09/pdf/williams.pdf [25 July 2008], pp. 10-13.

23. Yesilot, O., (2004) Tagiyev, Kaktus Publishing, Istanbul. 


\section{NOTES}

